\title{
Supporting families and carers during the inpatient admission
}

\author{
Michelle Roberts ${ }^{*}$, Michelle Hamlin \\ From 2013 ANZAED Conference: Inspiring Change: Person and Context \\ Melbourne, Australia. 23-24 August 2013
}

The Royal Brisbane and Women's Hospital Eating Disorder Unit is a Room: State wide public specialist service providing high quality support and intervention to adults requiring an inpatient admission to treat eating disorders.

Family members and carers play a significant role in providing support for their loved one both in the community and during inpatient admissions. A gap in service delivery was noted in the provision of support to families and carers during the inpatient admission. The identification of a nominated family worker (provided by the Social Worker) was developed to ensure that families and carers were able to access support and assistance in a timely manner.

In conjunction with this an information booklet was produced to be given to families on admission of their loved ones as a way of providing detailed, up to date information to better assist and improve the support family members received.

The information booklet was developed in conjunction with consumers, a paid carer representative and other eating disorder professionals.

This abstract was presented in the Care in Inpatient and Community Settings stream of the 2013 ANZAED Conference.

Published: 14 November 2013

doi:10.1186/2050-2974-1-S1-013

Cite this article as: Roberts and Hamlin: Supporting families and carers during the inpatient admission. Journal of Eating Disorders 20131

(Suppl 1):013.

\footnotetext{
* Correspondence: Michelle_A_Roberts@health.qld.gov.au
}

Royal Brisbane and Women's Hospital, Australia
Submit your next manuscript to BioMed Central and take full advantage of:

- Convenient online submission

- Thorough peer review

- No space constraints or color figure charges

- Immediate publication on acceptance

- Inclusion in PubMed, CAS, Scopus and Google Scholar

- Research which is freely available for redistribution

\section{() Biomed Central}

\section{Biomed Central}

